\title{
Sultan Sencer (Sancar) Dönemi (1119-1157) Selçuklularda Taht Mücadeleleri*
}

\author{
The Era of Sultan Sencer (1119-1157) and Power Struggles during the \\ Seljukide Period
}

\begin{abstract}
Abdullah BAYINDIR**
Özet

Bu çalışmanın konusu Selçuklu Devleti'nin hüküm sürdüğü yıllarda hanedan üyelerinin devlet idaresini ele geçirmek için giriştikleri taht mücadelelerinden, Sultan Sencer (Sancar) dönemini ele almaktadır. Çalışmada Sultan Sencer döneminde yaşanan taht mücadelelerine değinmekle beraber ülkenin diğer devletlerle olan münasebetlerine de bakılmıştır. Sultan Sencer'in Selçuklu Devleti'nin son hükümdarı olması hasebiyle Türk tarihinde önemli bir yere sahip olması ve yine Selçuklu Devleti için kader belirleyici bir rol üstlenmesi, işlenen dönemin önemini arttırmaktadır. Selçuklularda yaşanmış olan taht mücadelelerine birçok faktörün direkt etki ettiğini belirterek bu çalışmanın da doktora tezinden özetlenerek hazırlandığının altını çizmekte fayda vardır. Burada ele alınan konunun daha kapsamlı anlaşıılması ve detaylı bilgilerin aktarılması için hazırlanmış olan doktora tezinin incelenmesi önem arz etmektedir. "Selçuklularda Saltanat Mücadeleleri" başlıklı doktora tezi çalışmasında yalnızca Sultan Sencer dönemi değil Selçuklu Devleti içerisinde yaşanmış olan bütün taht kavgaları ayrı ayrı ele alınarak sebep ve sonuçları ile anlatılmaya çalışılmıştır. Bu yüzden burada işlediğimiz konu diğer ana konunun sadece küçük bir dönemini kapsamaktadır.
\end{abstract}

Anahtar Kelimeler: Selçuklu Devleti, Taht Kavgaları, Sultan Sencer.

\begin{abstract}
Abstact
This work discusses the era of Sultan Sencer, which includes dynasty members' struggle to take hold of state administration during the Seljuks reign. Besides the struggle of thrones, relationships with other states during the Seljuks' period are discussed in the work. Since the Sultan Sencer is the last ruler of the Seljuk State, who has a significant role in the Turkish history and in the Seljuk State, the period is getting importance. It is vital to point out that this paper has been produced by summarizing a doctoral thesis by emphasizing many factors affected the struggles of thrones in the era of the Seljuks. Understanding of the subject more comprehensively and more elaborative, not only Sultan Sencer period but also the struggles of thrones with reasons and results in the Seljuks period are discussed in the work. Thus, the subject includes a short period of the main topic.
\end{abstract}

Key Words: Seljuk State, Power Struggles, Sultan Sencer

\section{Giriş}

Saltanat Mücadeleleri çoğu zaman kardeşler arsında yaşanmasına rağmen bazı zamanlarda baba-oğul, amca, yeğen ve diğer aile mensupları arasında da yaşanmıştır(Koca,2009:2-5). Öte yandan saltanat makamına yüklenmiş olan kutsiyet ve ulaşılmazlık bu makamın cezbedici yönünü kuvvetlendirmiş̧ir. Hal böyle olunca da hanedan ailesi mensuplarından olan erkek fertler için mücadele kaçınılmaz duruma gelmiştir. Bunun yanı sıra saltanat makamını ele geçirmek bütün sorunları gidermek için yereli görülmemektedir; çünkü saltanatı elde tutmak, mücadele kadar önem arz etmektedir.

$\mathrm{Ne}$ yazık ki eski Türk devletlerinde saltanata kimin geçeceği kesin kurallarla çerçevelenmemiştir. Bu sorun ise saltanat mücadelelerin asıl sebeplerini teşkil etmektedir. Çünkü eski Türk devlet geleneğine göre ülke (devlet) hanedanın ortak malıdır anlayıșı, hanedan üyelerinin tahtı ele geçirmek için kullandığı en büyük gerekçedir. İşte Selçuklu Devleti'nin de bu anlayışa tabi bir yönetime sahip olması, devletin ömrü boyunca birçok saltanat mücadelelerine maruz kalmasına sebep olmuştur. Yeni bir hükümdarın seçilmesi gerektiğinde bütün hanedan üyelerinin aynı haklara sahip olması işte bu mücadeleleri tetikleyen şeydir. Malumdur ki bu durum saltanatın kısa ömürlü olmasına da etki etmiştir. Öyle ki devleti

\footnotetext{
${ }^{*}$ Bu makale Selçuklularda Saltanat Mücadeleleri adı Doktora tezinden çıkarılmıştır.

** Doktora öğrencisi, Gaziantep Üniversitesi Sosyal Bilimler Enstitüsü, Tarih Ana Bilim Dalı. abdullahbayindir27@gmail.com
} 
kökünden sarsan bu mücadeleler hanedan üyelerinin kendilerini güçlü gördükleri anlarda harekete geçmelerine sebep olmuştur. Yine anlayış çerçevesinde bakıldığında saltanat için mücadeleye girişen hanedan ailesi mensuplarının bu hareketlerinde haklı oldukları görülmektedir. Çünkü kendisini diğerleri gibi taht üzerinde eşit haklara sahip olduğunu bilmesi, saltanat makamını ele geçirmesi için yeterli sebep olarak görülmektedir. Buna bağlı olarak yeterli askeri güce ve kendinde Sultan olabilecek vasıfları gören hanedan üyeleri tahtı ele geçirmek için harekete geçmekten geri durmamışlardır.

Bunun yanı sıra ordu komutanlarının kendi makamlarını yükseltmek adına, kendilerine yakın gördükleri ve etkileri altına alabileceklerini düşündükleri hanedan üyelerini taht iddiacısı olarak öne sürmeleri de saltanat mücadelelerinde önemli bir yer tutmaktadır. Bu duruma örnek olarak Sultan Berkyaruk döneminde vezirlik görevi yürüten Müeyyidü'l-Mülk'ün Sultan tarafından azledilince, önce emir Üner'i daha sonra da sultanın kardeşi Muhammet Tapar'1 saltanat mücadelesi için kışkırtması ve teşvik etmesi gösterilebilir.

Öte yandan yaşanan saltanat mücadelelerinin çevre devletler için de ayrıca önem arz ettiğini söylemek gerekir. Öyle ki Selçuklu Devleti içerisinde yaşanan bu iç çekişmeleri firsata çeviren devletler bu isyanları zaman zaman destekleyerek rakip olarak gördükleri Selçukluların zayıflamasına sebep olmuşlardır.

Bütün bunlar göz önüne alındığında Sultan Sencer dönemi de diğer Selçuklu sultanlarının yaşamış olduğu iç buhranlar ve kargaşalarla doludur. Ele alınan Sultan Sencer dönemi de yine bir Sultan değişikliği sırasında ortaya çıkan saltanat mücadeleleri ile başlamıştır.

$\mathrm{Bu}$ bağlamda Sencer dönemine göz atacak olursak: Sultan Sencer (Sancar) ${ }^{1}$ Büyük Selçuklu Imparatorluğu'nda en uzun süre sultanlık yapmış son Selçuklu hükümdarıdır (Turan,2014:234). Horasan Melikliği dönemleri hariç (1098-1118) Selçuklu İmparatorluğu'nu 39 y1l (1118-1157) gibi uzun bir süre yönetmiş, ülkenin bütünlüğü ve devamlılığı konusunda oldukça gayretli çalışmaları ile dikkat çekmiştir. Nitekim Sencer'in bütün çabalarına rağmen, onun ölümünden sonra ülke dağılmaktan kurtulamamıştır (Yazıcı,2014:234).

Sultan Sencer, uzun bir dönem, yani kardeşi Sultan Berkyaruk zamanından beri ve yine Berkyaruk tarafindan görevlendirilmek suretiyle Horasan'a melik olarak atanmış ve burada Muhammet Tapar'ın ölümüne kadar müstakil bir şekilde yaşamıştır (Öngül,2014:233).Yine Sultan Sencer, bu bölgedeki melikliği süresince: Karahanlılarla, Gurlularla ve Gaznelilerle mücadele ederek onları kendine bağlamayı başarmıştır. Nitekim 18 Nisan 1118 tarihinde Sultan Muhammet Tapar'ın ölümü (Turan,2014:233-234; Öngül,2014:231; Mateos: 262) ile başlayan taht mücadeleleri Sencer'i de etkilemiş ve bir hanedan mensubu olarak bu mücadelelerden uzak duramamıştır (Köymen,1989:82-83; Yazıc1,2014:235).

Tablo 1: Selçuklu Sultanları Listesi

\begin{tabular}{|l|l|c|}
\hline $\mathbf{1}$ & Sultan Tuğrul Bey bin Mikhâil & $1040-1063$ \\
\hline $\mathbf{2}$ & Sultan Alparslan bin Çağrı Bey & $1063-1072$ \\
\hline $\mathbf{3}$ & Sultan Melikşah bin Alparslan & $1072-1092$ \\
\hline $\mathbf{4}$ & Sultan Berkyaruk bin Melikşah & $1092-1104$ \\
\hline
\end{tabular}

\footnotetext{
${ }^{1}$ Sencer; Melikşah'ın hayatta kalan çocuklarından birisidir. 6 Kasım 1086 tarihinde Elcezire bölgesindeki Sincar'da dünyaya gelmiştir. Doğum yerinden esinlenerek ona, Türkçede Saplayan manasına gelen Sencer adı verilmiştir. Nitekim kaynaklar bu ismin bir yakıştırmadan ibaret olduğuna dikkat çekmektedirler. Öte yandan Ahmet isminin de Sencer ile aynı kişi olduğu iddia edilmektedir. Daha fazla bilgi için bkz. O. Turan, (2014). Selçuklular Tarihi ve Türk İslam-Medeniyeti, s, 234; A. Sevim-E. Merçil, (2014). Selçuklu Devletleri Tarihi Siyaset, Teşkilat ve Kültür, s, 257; M. A. Köymen, "Sencer”, İA, X, ss, 486-489.
} 


\begin{tabular}{|l|l|l|}
\hline $\mathbf{5}$ & Sultan Muhammed Tapar bin Melikşah & $1105-1118$ \\
\hline $\mathbf{6}$ & Sultan Sencer bin Melikşah & $1119-1157$ \\
\hline
\end{tabular}

Kaynak: A. Öngül, (2014), Selçuklular Tarihi I Büyük Selçuklular, Irak, Kirman ve Suriye Selçuklularl, s. 519.

\section{Sultan Sencer'in Taht Mücadelesi}

Öz kardeşi Sultan Muhammed Tapar'ın ölümüne çok üzülen Sencer, kardeşi için Merv şehrinde yedi gün sürecek yas ilan ederek hutbeler, hatimler okutmuştur(İbnü'l Esir, X:433435; Sevim-Merçil,2014:258). Nitekim Sultanın, ölmeden önce en büyük oğlu Mahmud'u veliaht olarak göstermesi, Sencer'in kardeşinden sonra tahta oturma durumunu zora sokmuştur(Merçil, 1991:66). Babasının ölümünden hemen sonra tahta geçirilen yeni Sultan Mahmud henüz on dört yaşında olmasından ötürü devlet işlerinden anlamamakta ve devlet idaresine hükmedememektedir. Bu durum, ileri gelen devlet yöneticilerinin işine yaramış ve kendi istekleri doğrultusunda devleti yönetmeye başlamışlardır. Kaynaklarda bu devlet adamlarından özellikle Hacibü'l-Hüccab Ali Bar ve onun kâtibi konumundaki Ebu-l-Kasım Dergezinî'nin devlet yönetiminde söz sahibi olduğu görülmektedir(Yazıc1,2014:234). Devlet yönetimindeki kargaşa ve yönetim boşluğu sadece bununla da kalmamıștır. Sultan Mahmud'un küçük kardeşleri Şehzade Mesud ve Tuğrul Beyin atabekleri konumundaki Cüyuş Bey ile Gündoğdu Bey de firsattan istifade henüz küçük yaştaki şehzadeler adına saltanatta hak iddiası ile hareketlendikleri görülmektedir(Öngül,2014:234).

Bütün olan bitenin farkında olan Sencer hiç vakit kaybetmeden kendi sultanlığını ilan ederek Selçuklu tahtının asıl sahibinin kendisi olduğunu ilan etmiştir(14 Haziran 1118). Bu sırada Horasan 'da bulunan Sencer'in yeğeni Mahmud' dan daha tecrübeli olması sayıca az olan ordusunu onun üzerine gönderecek kadar cesaret sağlamasına yaramıştır. Bütün hazırlıklarını tamamladıktan sonra Mahmud'un üzerine harekete geçen Sencer, kısa süre içerisinde yeğeninden aldığı barış teklifine de, onun küçük yaşından ötürü Ali Bar ve kâtibi Ebu-l-Kasım gibi devlet adamlarının etkisi altında kaldığını söyleyerek olumsuz yanıt vermiştir. Neticede iki Selçuklu ordusu 11 Ağustos 1119 tarihinde Rey yakınlarındaki Save șehrinde karșı karşıya gelmişlerdir. Kaynaklarda iki ordudan Melik Sencer'in ordusunun 20 bin kişilik bir kuvvete sahip olduğu yazarken Sultan Mahmud'un 30 bin kişilik askeri birliğe sahip olduğu kaydedilmektedir(Sevim-Merçi1,2014:258-259).Öte yandan Sencer, belki de daha az askeri birliğe sahip olmasından ötürü bu savaşta filleri kullanarak üstünlük sağlamak istemiş olacak ki ortalama 18 ile 45 arasında bir fil birliğine sahip olduğu da yine kaynaklar tarafından aktarılmaktadır(Sevim-Merçil,2014:258-259; Yazıcı,2014:235). Neticede savaş esnasında ilk sıralarda Mahmud'un kalabalık ordusu üstünlüğü ele geçirmiş olsa da Sencer'in ordusundaki fillerin savaşa dâhil edilmesiyle durum Mahmud'un aleyhine dönmüştür. Sonuç olarak yenilen Mahmud, beraberindeki devlet adamları ile İsfahan'a çekilmek zorunda kalmıştır. Savaşta filleri kullanarak zekice bir iş yapan Sencer ise buradan Hemedan'a yönelmiş aynı zamanda Băgdat'a ulaşan galibiyet haberi ile de halifelik makamının Sencer adına hutbe okutmasını sağlamıştır(Öngül,2014:234-235). Böylelikle halifelik tarafından da sultanlığı onaylanan Sencer hem dini hem resmi mana da Selçuklu sultanı olarak ilan edilmiştir.

\section{Sultan Sencer İktidarı}

Yeğeni Mahmud ile giriştiği saltanat davasından sonra galip gelen Sultan Sencer, annesinin de etkisi ile yeğenini affederek canını bağışlamıştır. Sencer, oğlu olmadığı için Mahmud'u veliahdı yapıp kızı Mehmelek Hatun'u da onunla evlendirip damadı yapmıştır. Öte yandan Sultan Sencer'in yeğenini affetmesinden sonra tekrar taht iddiasında bulunabileceği şüphesi ile belli bir dönem onu kontrolünde tutup yetki vermediği bilinmektedir. Uzun bir süre Mahmud'u kontrolünde tutan Sultan tekrar güvenini kazanınca daha önceden yasaklanmış olan 
saltanat törenlerinde tekrar ona da yer verilmesine izin vererek adına "nevbet" onaylamıştır(Sevim-Merçil,2014:260).

Saltanat kavgaları yüzünden oldukça yıpranmış durumda olan devlet, Sultan Sencer'in saltanat mücadelesini kazanmasından sonra rahat bir nefes almıştır. Böylelikle kısa zaman içerisinde Selçuklu Devleti'ne tekrar istikrar kazandıran Sultan Sencer, Sultanü'l-a'zam (En Büyük Sultan )unvanını alarak Merv merkez olmak kaydıyla Rey, Mâzenderân ve Kumis gibi şehir ve bölgeleri egemenlik sahasına dâhil etmiştir. Veliahdı olarak atadığı yeğeni ve aynı zamanda damadı olan Mahmud'a ise Sultanü'l-mu'azzam (Büyük Sultan) ${ }^{3}$ unvanı ile Hemedan merkez olmak üzere ülkenin Batı yönündeki topraklarını yani Irak-ı Acem (Cibal)'in bir kısmı ile Irak-ı Arap (Mezopotamya) ve Suriye topraklarını vermiştir (Köymen,1991:4-28; Köymen,"Sencer":486-493). Burada Sencer'in ülkenin topraklarını yeğeni ile bölüşmesi sonucu Selçukluların yeni bir kolu olarak Irak Selçuklu Devleti'nin kurulmuş olduğunu da belirtmekte fayda vardır(Sevim-Merçil,2014:260; Öngül,2014:236).

Öte yandan Sultan Sencer, devletin hâkimiyet alanında bulunan bazı bölgeleri de diğer yeğenlerinin iktâsına vermiştir. Buna göre Irak-ı Acem eyaletinin yarısı ile Gîlân bölgesini Şehzade Tuğrul'a Fars Eyaletini, İsfahan ve Huzistân'ın yarısını ise Şehzade Selçukşah'ın kontrolüne bırakmıştır(Turan,2014:234-235; Kafesoğlu,1992:52; Köymen,2011:5-6).

Sultan Sencer hükümdarlığı süresinde yalnızca taht mücadeleleri gibi sıkıntılar ile uğraşmamıştır. Uzun zaman önce başlamış olan Batini hareketlerini bastırmak için de uzun uğraşlar veren Sencer, ülke için oldukça zararlı olan bu hareketi bastırmak için elinden gelen bütün çabayı göstermiştir. Öyle ki kaynaklarda Sencer'in bir defasında Bâtıniler üzerine yaptığı baskında 10 bine yakın fedainin öldürüldüğ̈̈ zikredilmektedir. Bu durum Sultan Sencer'in bu işi ne kadar ciddiye aldığını göstermektedir(İbnü'l Esir, X:498-502; Sevim-Merçil,2014:262$263)^{4}$.

Sultan Sencer her yönü ile bozulan devlet idaresini tekrar tesis etmeyi istemişse de ne yazık ki işler istediği doğrultuda gitmemiştir. Devlet içerisinde idarede söz sahibi olmak isteyen ve daha önceden bulunduğu konumda güç kaybı yaşamış gerek devlet erkânı, gerekse halifelik makamınca sultanlığı tehlike altına girmeye başlamıştır. Sultan ile tek başına mücadele edemeyeceğini anlayan saltanat iddiacıları ise bu durum karşısında ittifak kurarak emellerine ulaşmayı amaçlamışlardır.

\section{Sencer’e Karşı İttifak Girişimi}

Kaynakların bize aktardığına göre bu gelişmeler ışığında Abbasi Halifesi Müsterşid Billâh, Sultan Sencer'in artan otoritesi karşısında güç kaybetmiş ve bu durumdan hoşnut olmayan halife kurtulup eski gücüne kavuşmak için Sultanın yeğeni Mahmud ile ilişkilerini arttırmaya başlamıştır. Halifenin yaklaşımlarından rahatsız olmayan Mahmud, kurulan bu samimi ilişkiye ses çıkarmayarak olumlu yanıtlar vermiştir. Mahmud'un burada halife ile iş birliği içerisine girmesindeki amaç ise Sultan Sencer'in bağımlılığından kurtularak kendi hükümdarlığını ilan etmek istemesi olarak yorumlanabilir. Bu amaç doğrultusunda ikili, Sultan

\footnotetext{
${ }^{2}$ Hükümdarın çadırı veya saray kapısı önünde beş namaz vakti, tabi hükümdarlar ve diğer küçük devlet ileri gelenleri için üç namaz vakti ikametgâhları önünde çaldırılan musiki parçası. Daha fazla bilgi için bkz. E. Merçil, (2007). Selçuklularda Hükümdarlık Alâmetleri, TTK, Ankara, s, 116-117; A. Çayc1, (2008), Selçuklularda Egemenlik Sembolleri, İz Yayıncılık, İstanbul, s, 165-181.

${ }^{3}$ Selçuklu hükümdarlarının Metbu ve Tabi sıfatında kullandıkları unvanlarla ilgili daha fazla bilgi için bkz. M. A. Köymen, (1989). Selçuklu Devri Türk Tarihi, s, 97; E. Merçil, (2007). Selçuklularda Hükümdarlık Alâmetleri, TTK, Ankara, s, 30-34; A. Çayc1, (2008), age, s, 65-74; M. A. Köymen, (2016). Büyük Selçuklu Imparatorluğu Tarihi III, Alp Arslan ve Zamanı, TTK, Ankara, s, 74-89.

${ }^{4}$ Sultan Sencer döneminde Bâtıniler ile yapılan mücadeleler için ayrıca bkz. Pınar Kaya, (2013), Sultan Sencer Devrinde (1118-1157) Bâtıniler İle Yapılan Mücadeleler, Tarih Dergisi, S,58 (2), İstanbul, ss, 43-64.
} 
Sencer'e karşı bir ittifak kurarak savaş kararı dahi almışlardır(Sevim-Merçil,2014:263-264). Sultan Sencer bu durumu öğrendiği zaman, yeğeni Mahmud'a hemen bir mektup yazarak girdiği bu yoldan dönmesi çağrısında bulunmuştur. Daha önceden amcasına karşı giriştiği mücadeleyi kaybeden ve amcasının buna rağmen onu affedip tekrar yetkiler verip kızı ile evlendirmesini de göz önünde bulunduran Mahmud, amcasından aldığ 1 bu ikaza olumlu cevap vererek bu fikrinden vazgeçmiştir(Köymen,1991:83-111; Öngül,2014:238). Bunun üzerine Sultan Sencer, halifenin siyasi etkisine girmiş olan Mahmud hakkında şüphelerinden kurtulmak ve vezirinin de söylediklerinin yalan mı, doğru mu olduğunu anlamak üzere onu, Rey şehrinde tertiplediği bir yemeğe davet ederek amacını anlamaya çalışmıştır. Neticede yeğeninin yanlış yapmadığına kanaat getiren Sultan Sencer rahatlamış ve bu görüşmeden oldukça memnun olarak Hemedan'a gitmek üzere Rey şehrinden ayrılmıştır(İbnü’l Esir, X:514-515; Köymen,"Sencer":486-493).

$\mathrm{Bu}$ gelişmelerden sonra Sultan Sencer belki de yeğeni Mahmud'un sadakatini perçinlemek adına, daha önceden evlendirmiş olduğu kızı Mehmelek Hatun ölünce, diğer kızı Gevher Nesb Sultanı Mahmud ile evlendirmiștir. Nitekim akrabalık bağını kuvvetlendirmek için girişimde bulunan Sultan Sencer'in ikinci kızı da bir süre sonra vefat edince Sultan bu amacını gerçekleştirememiştir. Bunun yanı sıra halife Müsterşid'in kendisine yaptıklarını unutmayan Sultan Sencer, yeğenini onun üzerine göndermiştir. Nitekim yeğeni Mahmud önceden geçirmiş olduğu bir hastalığın bu sefer esnasında tekrar nüksetmesi ile fenalaşarak 10 Eylül 1131 tarihinde vefat etmiştir. Sultan Sencer halife üzerine yaptığı bu seferde yeğeninin ölmesi üzerine başarılı olamamıştır(Merçil,1991:66-67;Yazıc1,2014:236;Öngül,2014:241; Sevim-Merçil,2014:266).

Böylelikle kendisi için zaman zaman saltanat tehlikesi oluşturan yeğeni Mahmud'dan kurtulmuş olan Sultan Sencer, öte yandan devlet içinde saltanat kargaşasının tekrar çıkmasına da engel olamamıştır. Bu minvalde Mahmud'un ölümü ile Irak Selçukluları kolundan boşalan tahta, oğlu Davud geçerek babasının bütün yetkisini kendisi üstlenmiştir. Nitekim Mahmud'un diğer kardeşleri Mesud, Tuğrul ve Selçukşah, Davud'un bu hamlesinden hoşnut olmayarak karışıklıklar çıkarmaya başlamışlardır. Durumun daha kötüye gitmesinden korkan Sultan Sencer, kontrolü sağlamak için derhal müdahalede bulunmuştur(Turan,2014:238). Mahmud'un idaresinde olan Irak Selçukluları kolunu yönetmesi için aklında bulunan ismin Tuğrul olduğunu açıklayan ve Irak Selçukluları tahtına onu oturtmak isteyen Sultan Sencer, Tuğrul'un diğer kardeşleri ve halife Müsterşid'in tepkisi ve oluşturdukları ittifak ile karşı karşıya kalmıştır. Ne yazık ki olayları yatıştıramayan Sultan Sencer yeğenlerinin oluşturduğu ittifak karşısında savaşmaktan başka çare görememiş ve ordusunu hazırlatarak Rey şehrine kadar ilerlemiştir. Melik Mesud'un kontrolündeki ittifak güçleri ile karşı karıya gelen Sultan Sencer, yanında diğer yeğeni Tuğrul ile birlikte ittifak güçlerine karşı Dinever dolaylarında kıran kırana bir çarpışmaya girmiştir. Şiddetli bir savaş neticesinde yeğeni Melik Mesud ağır bir darbe alarak yenilgiye uğramış, ittifak kuvvetlerinin ordusu Sultan Sencer'in ordusu karşısında tarumar olmuştur. Nihayetinde Sultan Sencer, kanlı biten bir savaşın ardından Irak Selçukluları Devleti'nin başına, yeğeni Tuğrul'u geçirmeyi başarmıştır(Merçil,1991:67; Öngül,2014:242243; Sevim-Merçil,2014:266-269).

Fakat Tuğrul'un başa geçmesinden sonra olaylar bir türlü dinmek bilmemiş, kardeşleri tarafından saltanatı ele geçirmeye yönelik kargaşalar devam etmiştir. Nitekim Tuğrul bir taraftan devleti yönetmeye çalışırken öte yandan da kardeşlerinin isyanı ile mücadele etmek durumunda kalmıştır. Tuğrul, yine bu zaman zarfı içerisinde amansız bir hastalıkla da mücadele etmektedir ve gün geçtikçe de hastalık onu biçare duruma düşürmektedir. Nihayet 24 Ekim 1134 tarihinde hastalığın pençesinden kurtulamayan Tuğrul vefat etmiş, Irak Selçukluları tahtı yine boş kalmıştır. Bu bağlamda firsat gözeten Melik Mesud uzun zamandır istediği taht için 
hamle yaparak Irak Selçukluları yönetimini ele geçirmeyi başarmıştır(Sevim-Merçil,2014:269270; Köymen,2011:254-286).

Melik Mesud'un tahta geçişinde Sultan Sencer'in kararı veya onayının alınmadığ 1 görülmektedir. Buradan Sultan Sencer'in tekrar bir müdahalenin ülkede saltanat karışıklıkları çıkaracağı düşüncesi ile sessiz kaldığ1 düşünülmektedir(Sümer,"Mes'ûd",İA:134142;Köymen,"Sencer",İA:486-493). Melik Mesud Irak Selçukluları tahtına oturduktan sonra kendi başına buyruk hareket etme eğilimi içerisine girmiştir. Bu bağlamda kendi hükümdarlık sahasını genişletmek amacıyla bazı savaşlara girişmiş; ama ne yazık ki bu savaşlardan istediği sonucu alamamıştır. Bu durum, Mesud'un kendi başına hareket etmesinin pek de fayda getirmediğini göstermiştir. Bu bağlamda Sultan Sencer ile Rey şehrinde bir araya gelerek ona biat edip emrine uyacağı ile ilgili raporlar sunmuş, Sultan Sencer ise Mesud'un verdiği izahattan tatmin olmuş vaziyette ona güvendiğini dile getirerek kaygısız bir şekilde Horasan'a dönmüştür(Köymen,2011:283-300; Sevim-Merçil,2014:270).

\section{Sultan Sencer'in Diğer Devletler Karşısındaki Tutumu}

Sultan Sencer, hükümdarlığı süresince ülkenin refahını sağlamak için elinden gelen çabayı göstermiştir. Öyle ki bu süre içerisinde hanedan mensuplarının ortaya çıkardığı saltanat mücadeleleri ile baş etmeye çalışan Sultan, bu durumu kontrol altına aldıktan sonra ülkenin komşu devletleri ile olan ilişkileri üzerinde de durmuştur. Bu minvalde Irak Selçuklularında durum böyle iken diğer taraftan Sultan Sencer'in de desteğini alarak 1118 yılında tahta geçen Gazne Devleti Sultanı Behramşah'ın, 1134 tarihine kadar sakin ve refah içerisinde bir saltanat sürdüğü, bu süre içerisinde hiçbir isyan hareketine girişmeden Selçuklu Devletine bağl1 kaldığ1 görülmektedir(Merçil,1991:68). Ne yazık ki durum Gazne Devleti tarafından Selçuklu Devleti'ne her yıl ödediği 250 bin dinarlık vergiyi 1134 yılından sonra ödememesi ile bozulmaya başlamıştır. Bundan başka Behramşah, kendi halkına da zulmetmeye başlamış ve onların mallarına el koyarak zenginliğini arttırmaya çalışmıştır. Burada Behramşah'ın kendi hükümdarlık alanını genişletmek ve bağımsız bir hale gelmek istemiş olması etkili bir neden olarak görülebilir. Bu bağlamda eski itaatkâr tutumunu tamamen elden bırakan hükümdar Behramşah, yaptığı bu aykırı hareketler neticesinde güçlendiğini ve Selçuklulara karşı bir kuvvet olduğunu düşünmektedir.

Bütün bu yapılanlardan az zaman sonra haberdar olan Sultan Sencer hiç vakit kaybetmeden Behramşah'ı halkına karşı zulüm içinde olmasından ve özellikle de Selçuklu Devletine karşı olan bağlılığından kopmasından ötürü cezalandırmak istemiştir. Bu minvalde harekete kalkışan Sultan Sencer, mevsimin kış olmasına karşın Behramşah üzerine sefer tertipleyerek 1135 tarihinde ordusunu Merv'den harekete geçirmiştir(Sevim-Merçil,2014:271). Nitekim Selçuklu ordusun üzerine geldiği haberini alan Gazne hükümdarı onlarla baş edemeyeceğini düşünerek korkuya kapılmış ve derhal ülkeyi terk edip Hindistan'a kaçmıştır(İbnü'1 Esir, XI:33-38; Köymen,Sencer,İA:486-493). Behramşah'ın korkup kaçmasının ardından şehrin kontrolünü sağlayan Sultan Sencer, halkın sıkıntılarını giderdikten sonra Behramşah'1 bir daha bu tarz hareketlere girmeyeceğine yemin ettirerek affetmiş ve hükümdarlığını iade etmiştir(Merçil,2007:85-90; Köymen,2011:305-309).

Sultan Sencer, Gazne Devletinin yanı sıra Karahanlı Devleti teşkilatlanmasını da düzenlemiş daha melikliği döneminde burayla ilgilenen Sultan Sencer, sultanlığı süresinde de müdahalelerde bulunmuştur. Bu bağlamda mevcut Batı Karahanlı Devleti hükümdarı Arslan Han Muhammed, bir hastalık neticesinde felç olunca yönetimi oğlu Nasr ile birlikte ele almıştır. $\mathrm{Bu}$ süreç içerisinde Semerkant'ın dini liderlerinin çıkardığı bir isyan sonucunda Nasr öldürülmüş, Arslan Han, bu durum üzerine diğer oğlu Ahmed'i ortak hükümdar olarak atamıştır. Ahmet ise kısa süre zarfında olayları yatıştırmış, yalnız karışıklıkların ilk çıktığı esnada Arslan Han, Sultan Sencer'den yardım istemiş Sultan Sencer de bu yardım isteğine 
olumlu cevap vermiştir(Merçil,1991:67-68). Nitekim olayların yatışmış olmasına karşın sefer hareketinden vazgeçmeyen Sultan Sencer, bu yardım talebini de bahane ederek yönetimde ciddi değişiklikler yapmıştır. Bu minvalde Semerkant'in hâkimiyetini ele alan Sultan Sencer, Arslan'ın hükümdarlığına son vererek yerine sırasıyla; Hasan bin Ali, İbrahim bin Süleyman ve II. Mahmud'u hükümdar olarak tayin etmiştir(Turan,2014:237-239). Sultan Sencer'in bu tutumu yalnızca kendi ülkesinde değil diğer ülkeler üzerinde de etkili olduğunu ortaya koymaktadir.

Bundan başka Sultan Sencer, Harezm bölgesine de melikliği sırasında hâkim olmuş ve 1098 yılında Beryaruk tarafından Harzem'e, Harzemşah olarak atanmış Kutb el-Din Muhammed'i görevinde bırakmıştır. Kutb el-Din Muhammed yaşamı boyunca Sencer'e sadık kalmıştır. Kutb el-Din Muhammed'in 1128 yılında ölümüyle birlikte yerine oğlu Atsız, Sultan Sencer'in izniyle buraya Harzemșah olarak atanmıștır(Sevim-Merçil,2014:272). Atsız da ilk başlarda tıpkı babası gibi Sultan'a sadakatle bağlılığını bildirmiştir; fakat daha sonra Cend ve Mangışlak gibi askeri bakımdan stratejik değeri olan yerleri ele geçirmesiyle birlikte hatırı sayılır bir kudrete erișmiştir. Atsız bu yerleri ele geçirirken Sultan Sencer'den icazet almadığ1 gibi, bu bölgede kâfirlere karşı savaş veren Müslüman halk1 da öldürmüştür(Öngül,2014:246247). Bu durumdan hiç de hoşnut olmayan Sultan Sencer, kendisinden bağımsız hareket eden atsızın güçlenmesini engellemek amacıyla onun üzerine bir sefer düzenleme kararı alarak 1138 yılında ordusunu hazırlatarak üzerine yürümüş ve onu mağlup ettiği gibi Harezm 'in de zaptını sağlayarak bölgeyi yeğeni Gıyaseddin Süleymanşah bin Muhammed'e bırakmış ve akabinde Merv'e dönmüştür(Kafesoğlu,2000:45-50).

Nitekim Merv'e dönen Sultan Sencer'den sonra işler pekte olumlu yönde seyretmemiş, Sencer'in Harezm'den ayrıldı̆̆ 1 haberini alan Atsız derhal harekete geçerek Süleymanșah ile mücadeleye girişmiştir. Neticede 1141 tarihinde meydana gelen savaşta Süleymanşah'1 mağlup eden Atsı, Harezm'e tekrar hâkim olarak hükümdarlığını ilan etmiştir(Köymen,2011:310-323; Merçil,1991:68).

Durum karşısında henüz müdahaleye firsat olmadan Karahıtaylıların Maveraünnehir bölgesinde görülmesi Harezm hükümdarı Atsız'ı endişelendirmiş ve Sultan Sencer'e bağlılığını bildirerek kendini sağlama almak istemiştir. Hal böyle olunca Sultan Sencer Atsız'ın daha önce yaptığı yanlışları ve itaatsizliği görmezden gelerek bağlılığını kabul edip destek sağlamıştır(Köymen,2011:310-321; Kafesoğlu,2000:48-49; Öngül,2014:247).

Bu gelişmelerin ardından Sultan Sencer'in ilgilenmek zorunda kaldığı diğer bir mesele olarak ortaya çıkan Karahıtaylılar Sultanı oldukça uğraştırmıştır. Bu bağlamda Karahanlı hükümdarı Mahmud ile egemenliği atında bulunan ve yine bir Türk boyu olan Karluklular arasında büyük bir anlaşmazlık çıkınca, bu sorun ile tek başına baş edemeyeceğini anlayan Karahanlı hükümdarı Mahmud, Sultan Sencer'den yardım isterken, Karluklularda buna karşılık Karahıtaylılardan yardım istemiştir(Sevim-Merçil,2014:273; Köymen,2011:322-335). Sultan Sencer, bu yardım isteği üzerine büyük bir ordu toplayarak harekete geçmiştir. İki kuvvet, 9 Eylül 1141 tarihinde Semerkant yakınlarında bulunan, Katvan bozkırında karşı karşıya gelmişlerdir(İbnü'1 Esir,XI:31-33; Öngül,2014:247-249). Nitekim Karahıtaylıların 100 bin kişilik ordusu karşısında ağır bir yenilgi alan Sultan Sencer, savaş meydanından kaçarak canını zor kurtarmıştır(Turan,2014:241; Yazıc1,2014:237).

Sultan Sencer'in aldığı bu ağır yenilgi ordusunun tamamen dağılmasına ve daha kötüsü eşi Terken Hatun ve emirlerinden Kumaç'ın da esir düşmesine sebep olmuştur(Kafesoğlu,2000:52-55). Yapılan bu savaşta hayatının ilk yenilgisini alan Sultan Sencer, Ceyhun nehri ötesinde kalan ve Çin hudutlarına kadar uzanan topraklardaki bütün ülkelerini kaybetmiştir(Sevim-Merçil,2014:274-276). Öyle ki Katvan bozkırlarında yapılan savaş mağlubiyeti Selçuklu Devleti ve İslam dünyası açısından ağır bir darbe olmuş, aynı 
zamanda Türkistan toprakları ilk defa putperest bir kavimin hâkimiyet sahasına dâhil olmuştur(Kafesoğlu,1992:53-54; Öngül,2014:249). Yine bu bağlamda, Katvan mağlubiyeti aynı zamanda Türk-İslam dünyasının bundan sonra doğudan gelebilecek herhangi bir istila karşısında mukavemetinin de kalmadığını göstermektedir(Turan,2014:241-242).

Sultan Sencer'in düştüğ̈̈ bu zor durumu firsata çevirmek isteyen Harezmşah Atsız Sultana olan bağlılık yeminini bozarak hiç vakit kaybetmeden Karahıtaylılarla iletişime geçmiş onlardan aldığı destek sayesinde Ekim 1141 tarihinde önce Serahs'1 daha sonra da Selçukluların payitahtı Merv'i istila ederek ele geçirmiş, Sultan Sencer'e ait olan hazineleri yağma etmiştir(Merçil,1991:69). Atsız daha da ileri giderek Sultanın adını hutbeden kaldırarak kendi adına hutbe okutmuş ve yine kendi adına tuğra çekmeye de başlamıştır (28 Mayıs 1142)(SevimMerçil,2014:277). Nitekim Atsız'ın göz açıp kapayana kadar yapmış olduğu bu ciddi değişiklikler halk tarafından şiddetle karşılanmış ve ayaklanmaya varan karşı çıkışlar peyda olmuştur. Öte yandan halkın tepkisini gören diğer Horasan şehirleri de Atsız'a karş1 mukavemet göstermeye başlamışlardır(Kafesoğlu,2000:56-57). Nitekim Atsız bu mukavemetin karşısında hiç de geri adım atmamış, elde ettiği hâkimiyet alanını kaybetmemek adına şiddete başvurmaktan çekinmemiştir. Bu bağlamda Atsız, Sultan Sencer'in himaye edip yetiştirdiği âlimleri ve din adamlarını kendine karşı isyan girişiminde halkı ayaklandırdığını görünce 20 Ekim 1141 tarihinde hışımla hareket ederek bu âlim ve din adamlarının çoğunu öldürterek infaz etmiştir(Sevim-Merçil,2014:276). Bütün bu olanlar karşısında elinden geleni yapmaya çalışan Sultan Sencer, alelacele toparlayabildiği kuvvetlerle Atsı'ın üzerine yürümüş, Sultan'ın toparlanıp üzerine geldiği haberini alan Atsız ise bazı din adamlarını ve âlimleri de yanına alarak Harezm'e doğru kaçarak çekilmiştir(Öngül,2014:250). Bu gelişmelerden sonra Atsız, Sultan Sencer'in kendini toparlanmasına firsat vermeden sonraki yıl da rahat durmamış Nişabur, Beyhak ve Horasan'ın kalan kısımlarını da kendi egemenliğine katmıştır(İbnü'l Esir,XI,84-85; Köymen,2011:342-345).

Bütün bu olumsuz gelişmelere rağmen Sultan Sencer, Katvan mağlubiyetinin ardından bütün becerisini ve gücünü kullanarak bir yıl içerisinde eski gücüne kavuşmayı başarabilmiş ve derhal Atsız'ın bu ilerleyişinin önünü almak adına 1143 yılında Harezm'e doğru bir sefer düzenlemiştir. Harezm'in merkezi konumundaki Gürgeç'e kadar ilerleyen Sultan, şehri kuşatmış ve Atsız'ı kıskaca almıştır. Bu durum üzerine Atsız, kurtulamayacağını anlayarak tekrar bağışlanma talebiyle Sultan'la temasa geçmiştir. Atsız'ın af talebine bu sefer de olumlu olarak karşılık veren Sultan Sencer, büyüklüğünü bir kez daha göstermiştir(Köprülü,’Harizmşahlar”,İA:265-267).

Bu affa mukabil Harezmşah Atsız, Merv'de ele geçirdiği, Sencer'e ait hazineleri iade edecek ve Sultan'a koşulsuz biat edecektir(Öngül,2014:251). Atsız bütün bu olanlardan sonra isyankâr tavrından vazgeçmemiş, hatta bu defa Sencer'i öldürmeyi tasarlayarak bu doğrultuda iki Bâtıni suikastçıyı Sencer'i öldürmesi için görevlendirmiştir(Sevim-Merçil,2014:277). Bu suikast, daha önceden Sultan tarafından Atsız'1 kontrol altında tutmak için görevlendirilen devrin ünlü şairlerinden ve Sencer'in elçisi Edip Sâbir tarafindan Sultan'a haber verilmesi üzerine uygulanamamıştır. Atsız, planının bozulması ve suikastın gerçekleşememesini şair Edip yüzünden olduğunu öğrenmesi üzerine Edip Sâbir'i Ceyhun nehrine atmak suretiyle boğdurarak öldürtmüştür ${ }^{5}$. Bu durum Sultan Sencer'i üçüncü kez Harezm'e sefer yapmak mecburiyetinde bırakmıştır. Olaylar bu yönde gelişince hazırlıklarını tamamlayan Selçuklu ordusu Harezm yolunu tutarak kuşatmayı tekrar başlatmıştır. İki aylık bir kuşatma sonrası

\footnotetext{
${ }^{5}$ Kaynaklarda bu olay; Elçi Edip Sâbir, Atsız'ın suikast planını haber aldıktan sonra kiralık katillerin eşkâlini bir kâğıda çizerek yaşlı bir kadının ayakkabısının içerisinde Sultan Sencer'e göndermiştir. Sultan bu istihbarat bilgisi üzerine iki adamı arattırmış ve bu iki kişi bir meyhanede bulunarak öldürülmüştür. Şeklinde aktarılmaktadır. Sultan Sencer'e yapılan suikast girişimi ile ilgili daha fazla bilgi için bkz. A. Sevim-E. Merçil, (2014). age, s, 276-277; A. Öngül, (2014), Selçuklular Tarihi I Büyük Selçuklular, Irak, Kirman ve Suriye Selçukluları, s, 251.
} 
Hezaresb Kalesi'ni almağa muvaffak olan Sultan Sencer'in ordusu Gürgenç'e doğru ilerleyişini sürdürmeye devam etmiştir. Bu durum üzerine endişeye kapılan Atsız, tekrar af dilemiş ve Sultan Sencer'e birçok hediye göndererek canını kurtarmıştır6.

Aslında Sultan Sencer'in Atsız gibi isyancı birinin yaptığı affedilemez davranışlara rağmen onu üç kez üst üste bağışlamasının bir nedeni vardır: Selçukluların kuzey bölgelerinde bulunan, henüz İslamiyet'i kabul etmemiş Türklerin güneye inmesini önleyecek pozisyonda hüküm süren ve bu Türklerle savaşan Atsız, aynı zamanda Karahıtaylılara yıllık 30 bin dinar vergi ödeyerek onlara iyi geçinmektedir. Yani kuzey yönünde bir tampon görevi gören Harezm, Selçuklu Devleti'nin kuzey kapısı konumundadır(Barthold,1990:349-350; Köymen,2011:336).

Diğer yandan Selçukluların, Gurlular ile de ilişki içerisinde olduğu bilinmektedir. Hatta Sultan Sencer döneminde Selçuklu-Gurlu ilişkilerinde bir de savaş mevcuttur (24 Haziran 1152). Selçukluların almış oldukları Katvan mağlubiyeti sonrası Gurlular, Herat'ı ele geçirmiş, Belh 'e kadar da ilerlemişlerdir. Bu gelişmeler üzerine Gurlular' $ı$ durdurmak amaciyla, Selçuklu kumandanı Emir Kumaç harekete geçmiş nitekim bu hareketinde başarılı olamamıştır. Emir Kumaç ile yaptığı savaşı kazanan Gur hükümdarı Alâeddin Hüseyin buradan güç alarak Selçuklulara ödediği yıllık vergiyi de ödememeye başlamıştır. Diğer taraftan Gaznelilerle de savaşa tutuşan Alâeddin Gazne'yi zapt etmiş ve halkı kılıçtan geçirmiştir(Merçil,2007:88-91). Öte yandan Gazne'de yedi gün yedi gece sürecek bir yangın çıkarmış olan Alâeddin, bu davranışından ötürü Cihânsûz (Dünyayı yakan) lakabını almıştır. Lakin Batıdan Sultan Sencer'in baskısı ile karşı karşıya kalan Alâeddin Gazne 'yi daha fazla elinde tutamadan Gur'a çekilmek zorunda kalmıştır. Diğer taraftan itaatsizliğinin yanı sıra bağımsızlığını da ilan etmiş olan Alâeddin Hüseyin artık çizmeyi aşmış duruma gelmiştir. Bunun üzerine Sultan Sencer, Alâeddin'in üzerine bir sefer yapmaya mecbur kalmış, 24 Haziran 1152 tarihinde Herat yakınlarında $N a ̂ b$ denilen yerde karşılaşan iki ordu savaşa tutuşmuş ve neticede Alâeddin Hüseyin kesin bir yenilgi alarak Sultan Sencer'e mağlup olmuştur(Turan,2014:242-243; Köymen,2011:378-380). Savaş neticesinde Alâeddin Hüseyin, Sultan Sencer'e esir düşmüş ve bir süre yanında, ona hizmetlerde bulunmuştur. Kendisini Sultan Sencer'e sevdirmeye muvaffak olan ve Sencer tarafindan affedilen Alâeddin Hüseyin Gur'un idaresine tekrar yetkilendirilerek bağışlanmıştır(Sevim-Merçil,2014:280-281; Öngül,2014:252-253; Merçil, 1991:69).

\section{Sultan Sencer'in Esirlik Dönemi}

Sultan Sencer'in Gurlularla mücadelesinin akabinde döneminin en ciddi sayllabilecek olaylarından biri olan Oğuzlar ile münasebeti oldukça dikkat çekmektedir. Çünkü Sultan Sencer bu ilişki neticesinde esir edilmiş uzun sayılabilecek esirlik hayatı hem onun hem de Selçuklu Devleti'nin durumunu ciddi şekilde etkilemiştir. Bu bağlamda Selçuklu ve Oğuzlar arasındaki münasebetlere bakıldığında; Karahıtay ve Karlukların baskısıyla Türkistan'dan Batıya doğru göç etmiş, göçebe bir yaşam süren Oğuzlar ${ }^{7}$, Tohâristan bozkırlarında, yarı bağımsız bir biçimde yaşamaktadırlar ${ }^{8}$. Buna bağlı olarak Ŏguzlar, Selçuklu hükümdarı Sultan

\footnotetext{
${ }^{6}$ Atsız'ın affedilmesine aracı olan, yiyeceğini ve giyeceğini ceylan eti ve derisinden karşıladığı için namına Ahupuş denen derviş vesile olmuştur. Bu derviş Sultan'a giderek Atsı'ın affedilmesi ile ilgili elçilik yapmıştır. Daha fazla bilgi için bkz. A. Sevim-E. Merçil, (2014). age, s, 279; A. Öngül, (2014), age, s, 251; Mehmet Fuat Köprülü, "Harizmşahlar", İA, s, 267; M. A. Köymen, (2011), Büyük Selçuklu Imparatorluğu Tarihi II- İkinci Imparatorluk Devri, TTK, Ankara, s, 335-353; İbrahim Kafesoğlu, (2000), Harezmşahlar Devleti Tarihi (485618/1092-1221), TTK, Ankara, s, 56-59.

${ }^{7}$ Ayrıca yirmi dört Oğuz boyunun Üç-ok ve Boz-ok adı ile on ikişer boy olarak iki kola yarıldıklarına dair ilk tarihi bilgi de bunlar hakkında verildiği kaynaklarda geçmektedir. Daha fazla bilgi için bkz. İbnü'l Esir, XI, s, 32; O. Turan, (2014). age, s, 244.

${ }^{8}$ Oğuzların bu bölgeye gelmeleri ve ortaya çıkan sorunların ayrıntılı bilgisi için ayrıca bkz. O. Turan, (2014). age, s, 243-244; A. Öngül, (2014), age, s, 254.
} 
Sencer'e y1lda 24 bin koyunu da vergi olarak vermekteydiler. Sultan Sencer ile Oğuzlar arasında çıkan ilk anlaşmazlık işte bu verginin tahsilâtı esnasında ortaya çıkmıştır. Vergi tahsilâtına gelen Selçuklu memurlarının güçlük çıkarması üzerine, Ŏ̆uzlar tarafından öldürülmesi Selçuklu-Oğuz anlaşmazlığının fitilini ateşlemiştir(Sevim-Merçil,2014:281). Bu olay üzerine Belh valisi olan Emir Kumaç bu olayın peşine düşmüş ve kendisini Oğuzların yaşadığ1 topraklar üzerine Şıhne (Vali) tayin ettirmiştir. Oğuzlardan bu memurların hesabını soran Emir Kumaç, Oğuzların kendileriyle uğraşmamasını, otlaklarında rahat bırakılmalarını istemelerine rağmen bu konu da ikna olmamış ve 10 bin kişilik bir orduyla Oğuzların üzerine yürümüştür(Öngül,2014:254; Sevim-Merçi1,2014:281). Durum karşısında Oğuzlar, Emir Kumaç'a bir anlaşma teklif etmişlerdir. Anlaşmaya göre çadır başı 200 dirhem vererek bulundukları otlakta kalmayı ve onlara dokunulmamasını istemişlerdir. Nitekim Emir Kumaç Oğuzlardan tamamen kurtulmak niyetiyle bu teklife sıcak bakmamış ve savaşmayı tercih etmiştir. Kendine ve ordusuna güvenen Emir Kumaç, verdiği bu kararın tamamen yanlış olduğunu çok zaman geçmeden anlamıştır. Çünkü $O \breve{g} u z$ birlikleri muhteşem savaş taktikleri ile sergiledikleri mücadelede Emir Kumaç'ın birliklerini darmadağın etmişlerdir. 1153 yılında meydana gelen bu savaş neticesinde Emir Kumaç ve oğlu Alâeddin Ebu Bekir, Oğuzlara esir düşmekten kurtulamamış ve daha sonra da hiç acımadan öldürülmüşlerdir(Merçil,1991:6970).

Bu olayı haber alan Sultan Sencer, Emir Kumaç'ın aldığı bu ağır yenilginin ardından Ŏguzların sandığ 1 kadar güçsüz olmadığını anlamış ve daha önceden sefer yaparak bu sorundan kurtulmak istemesine rağmen şimdi tereddüt içerisine girmiştir. Nitekim Oğuzlar üzerine sefer yapmaya çok hevesli olmasa da etrafındaki komutanlar ve özellikle de Emir Kumaç'ın torunu Mü'eyyed Ay-Aba'nın 1srarları karşısında cevapsız kalarak sefer yapmaya razı olmuştur. Bu arada rivayete göre Oğuzlar, Sultan Sencer'i savaştan vazgeçirmek için 50 bin at ve deve, 200 bin koyun 200 bin altın, 1000 köle ve türlü hediyeler vermeyi teklif etmişlerdir; lakin komutanlarının etkisinde kalan Sultan Sencer bu teklifleri reddederek seferi yapmaktan vazgeçmemiştir(Sevim-Merçi1,2014:281; Öngül,2014:252-253; Turan,2014:245). Burada dikkat çeken bir husus Oğuzların savaşmamak için ellerinden geleni yaptıkları hususudur. Çünkü otlaklarında rahat bırakılmak istediklerini defalarca bildirmelerine, hatta Selçuklu birliklerini bozguna uğratmalarına rağmen savaştan uzak durmak istemeleri barış içerisinde yaşamayı tercih ettiklerinin göstergesi sayılabilir. Bu minvalde nihayet iki ordu Mart-Nisan 1153 tarihinde Belh yakınlarında karşı karşıya gelmişlerdir. İlk önce Oğuzlar tarafından püskürtülen 100 bin kişilik Selçuklu ordusu, akabinde dar bir boğazda sıkıştırılarak ağır bir yenilgi uğratılmıştır(Sümer,1992:104-105). Oldukça kanlı geçen savaşta özellikle birçok Selçuklu Emir ve komutanın hayatını kaybetmesi dikkat çekicidir. Bunun dışında daha önemli bir savaş neticesi ise Sultan Sencer'in Ŏguzlar tarafından esir alınmış olmasıdır(Köymen,2011:410-412).

Oğuzlarca esir edilen Sultan Sencer, Oğuzlar tarafından uzunca bir müddet kullanılmıştır. Öyle ki Oğuzlar gittikleri her yere yanlarında Sultan Sencer'i de alarak hareket etmişlerdir. Bu sayede onun namını kullanarak başta Merv olmak üzere Horasanın tüm şehirlerinde Çağrı Bey zamanından beri dolu olan hazineleri yağmalayıp istila etmişlerdir. Bir istila hareketi başlatan ve bu harekete karşı gelenleri kıyımdan geçiren Oğuzlar daha sonra Belh ve Merv bölgesine çekilmişlerdir(Sevim-Merçil,2014:281-282).

Diğer taraftan boş kalan Selçuklu tahtına, Oğuzlarla yapılan bu savaştan kaçmayı başarmış olan ve bu esnada Bavendiler ülkesinde bulunan Sultan Sencer'in yeğeni Sultan Muhammet Tapar'ın oğlu Süleymanşah, vezir Tâhir Bin Fahr el-Mülk'ün gayretleriyle 11 Eylül 1153 tarihinde Nişabura getirilerek Selçuklu Sultanı ilan edilmiştir. Bu gelişmenin ardından fazla vakit kaybetmeden harekete geçen Süleymanşah, ilk etapta Ŏguzlar üzerine bir sefer tertipleyerek onlara ağır bir yenilgi verdirmiştir. Fakat ne yazık ki bütün Selçuklu Emir ve 
kumandanlarını razı edip etrafinda toplamayı başaramayan Süleymanşah, Merv üzerine bir sefer başlatmışsa da başarılı olamayarak Nişabur'a geri dönmüştür(Öngül,2014:255).

Oğuzlar ise bu gelişmelerden sonra Merv'e geçerek burayı iki ay boyunca yağmalamış, servetini vermeyen halka ise işkenceler yapmışlardır. Bunun yanı sıra Sultan Sencer'i de yanlarında götüren Oğuzlar, onu sıkı kontrol altında tutmakta ve hizmetçilerini her hafta düzenli şekilde değiştirmektedirler. Daha kötüsü ise Ŏguzlar Sultan Sencer'i geceleri bir kafese hapsedip burada tutuyorlar ve ona bir esir muamelesi yapıyorlardı. Çok zor zamanlar geçiren Sultan Sencer, Oğuzların ona, sen hala hükümdarsın demelerine inanmış ve bu yaptıklarının onu korumaya yönelik olduğunu sanmıştır. Fakat Ŏguzların son yaptıklarından sonra durumun farkına varan Sultan Sencer, Oğuz başbuğlarından Bahtiyar'ın Merv'i kendisine ikta olarak verilmesini istemesi üzerine bu işin tamamen bir oyun olduğu anlamıştır(Öngül,2014:255; Sevim-Merçil,2014:281-282; Turan,2014:246; Göksu,2010:79-110).

Öte yandan Süleymanşah, vezir Tahir Bin Fahr el-Mülk'ün Aralık 1153-Ocak 1154 tarihinde ölmesi üzerine büyük bir destekten mahrum kalmış ve iyice zayıflamıştır. Süleymanşah bütün çabalarına rağmen devleti toparlamak istese de Selçuklu Devleti büsbütün dağılmıştır. Bunun üzerine Süleymanşah Horasan'dan ayrılarak Cürcan'a gitmiştir(İbnü'1 Esir,XI,151-152). Oğuzlar ise daha sonra Tus şehri üzerine yürüyüp buraları istila etmiş ve bazı türbeleri harap ederek kullanılmaz hale getirmişlerdir. Öyle ki bu akıbetten Meşhed'de nasibini almıştır(Sevim-Merçil,2014:282-283). Bu gelişmelerden sonra, kaynaklara göre, Süleymanşah'in Horasandan ayrılmasından sonra çökmüş durumdaki devleti tekrar toparlamak adına Selçuklu Emirleri Aralık 1154-Ocak 1155 tarihinde, Sultan Sencer'in yeğeni ve Karahanlı hanedanından olan Arslan Han'ın oğlu Mahmud'a haber göndererek onu hükümdar yapma girişiminde bulunmuşlardır. Bağdat'da halen Sultan Sencer adına hutbe okunmasına rağmen Mahmud adına hutbe okutup ona itaat eden Selçuklu Emirleri, Oğuzlar'a karşı birlik olmak için ellerinden geleni yapmışlardır. Bu bağlamda Irak Selçuklu Sultanı Muhammed Bin Mahmut ve Harezmşah Atsız da bu desteğe katılarak Mahmud'un Sultanlığını kabul etmişlerdir. Selçukluların birlik olma girişimleri sırasında Oğuzlar da boş durmamış ve bu esnada Nişabur'a doğru hareket etmişlerdir. Nişabur'da da kendilerine karşı duracak kimse olmayınca burayı da yağma ve istila ederek Herat' $\imath$ kuşatma altına almaya başlamışlardır. Mahmud Han bu durum karşısında beraberinde Selçuklu Emirleri ile Herat'ı kuşatmakta olan Oğuzlar üzerine saldırmış nihayet çoğunluğunu Selçuklu ordularının kazandığı birçok irili ufaklı çatışma ve savaştan sonra Mahmud Han'ın çabaları sonuç vermiştir. Oğuzlarla anlaşma yapan Mahmud Han, onların bölgeden çekilesini de sağlamıştır. Yaşanan bu olumlu gelişmeler karşısında diğer bir sevindirici haber de Sultan Sencer'in tutsaklıktan kurtulması olmuştur(Sümer,1992:102-107; Turan,2014:246-248; Köymen,2011:399-414).

Öyle ki, Sultan Sencer'in tutsaklıktan kurtulması olayı kaynaklarda şu şekilde aktarılmaktadır: Ŏguzlarla yapılan anlaşma gereği Sultanın bazı eski kumandanlarına onunla görüşme izni verilmiştir. Bu bahaneye dayanarak 1156 tarihinde Sultan Sencer'in tutsaklıktan kurtulmasını sağlayan Müeyyed Ayaba önderliğinde Sultanın bazı has adamları bir gün Sultan Sencer'in yanına gelmiş ve bazı $O \breve{g} u z$ askerlerini para vaadi ile kandırarak Sultan Sencer'i Tirmiz şehri karşısındaki Ceyhun nehrinin kıyısına getirip oradan da Tirmiz şehrine kaçırmayı başarmışlardır ${ }^{9}$.

Uzun bir tutsakl1k yaşamından sonra Sultan Sencer derhal, Tirmiz'den Merv'e hareket ederek buradan kendisine tabi olan veya olmayan bütün çevre devletlere haber gönderip tekrar

\footnotetext{
${ }^{9}$ Bazı kaynaklar Sultan Sencer'in esirlikten kurtulma tarihlerini farklı verdiği bilinmektedir. Bunun için ayrıca bkz. A. Öngül, (2014), age, s, 256; M. A. Köymen, (2011), age, s, 454-455; A. Sevim-E. Merçil, (2014). age, s, 283; O. Turan, (2014). age, s, 246.
} 
devletin başına geçtiğini bildirmiştir(Sümer,1992:105-107). Bunun yanı sıra Horasan Emir ve askerleri de onun etrafında toplanmakta gecikmemişlerdir(İbnü'l Esir, XI, 178-180).

Nitekim Sultan Sencer Merv'de Selçuklu Devletini tekrar toparlamaya çalışmıştır; fakat bu toparlanma girişimleri pek de fayda etmemiştir; çünkü artık yaşlanmış olan Sultan Sencer, esirlik dönemi boyunca ruhen oldukça yıpranmıştır. Bundan başka boşalan devlet hazineleri maddi anlamda devleti oldukça zayıflatmış ve bu durum daha ciddi sıkıntıları beraberinde getirmiştir. Zira eski düzeni sağlamak hem dinç ve sağl1klı bir zihin hem de güçlü bir devlet hazinesi gerektirmektedir. Aynı zamanda dağılmış askerlerin toparlanamaması ve harap olmuş ülkenin bitkin hali, Sulatan Sencer'in bu son çırpınışları karşısında ne yazık ki değişmemiştir(Öngül,2014:257; Köymen,2011:454-459).

Üç yıllık esaretin ardından başında bulunduğu devleti kurtarma girişimleri ve devlet düzenini tekrar tesis etme isteğine rağmen yaşlanmış olan Sultan Sencer 6 Mayıs-Nisan 1157 yılında 71-72 yaşlarında hayatını kaybetmiştir. Sultan Sencer, ölümünden sonra, Merv şehrine sağ iken yaptırmış olduğu, Ahret Evi (Dar ul-ahiret) veya Devlet Hane adı ile bilinen görkemli türbeye defnedilmiştir(İbnü'l Esir, XI:186-187; Köymen,2011:464-465; SevimMerçil,2014:283-284; Turan,2014:246).

\section{Sonuc}

Türk hâkimiyet mefkûresine göre yönetilen Selçuklu Devletinde, meydana gelen saltanat mücadeleleri ne yazık ki devletin kuruluşundan yıkılışına kadar devam etmiştir. $\mathrm{Bu}$ mücadeleler devletin şekillenmesinde ve gelişmesinde önemli derecede olumsuz etkiye sahip olmuşlardır. Bu sebeptendir ki, kısa süre içerisinde sınırları imparatorluk seviyesine kadar çıkan devlet, yine kısa bir süre içerisinde dağılmaya yüz tutmuş̧tur.

Hemen her Sultan değişiminde ortaya çıkan bu sorun, devletin kısa bir süre içerisinde sonunu getirmiştir. Sultan Sencer dönemi de bu sebepten doğmuş mücadeleler eşliğinde geçirilen bir saltanat dönemidir.

$\mathrm{Bu}$ bağlamda bakıldığında, Türk-İslam tarihinde ilk kez sınırları Çin topraklarından Marmara Deniz'i kıyılarına kadar uzanan ve dahi oradan Kafkasya ve Misır'a dek; Harezm, Türkistan, Afganistan, Iran, Azerbaycan, Irak, Suriye ve nihayetinde Anadolu topraklarını içerisine alan oldukça geniş bir coğrafyada kısa sürede imparatorluk kuran Selçuklular, Türk ve dünya tarihine yön veren önemli bir Türk devleti olarak karşımıza çıkmaktadır.

Selçuklu Imparatorluğu'nun bu kadar geniș coğrafyaya kısa sürede hâkim olmasına rağmen, bir imparatorluk olarak çok kısa sayılabilecek bir tarihe sahip olduğu görülmektedir. Bu durumun sebebi olarak, çalışmamızın da konusunu oluşturan, Türk devlet geleneğine uygun olarak yönetilen Selçuklu Devleti'nin kuruluşundan yıkılışına kadar yaşamış olduğu hanedan üyeleri arasındaki saltanat mücadeleleridir. Eski Türk devlet töresi ve geleneğine göre ülke devleti kuran hanedan üyelerinin ortak malıdır anlayışı, sultanın ölümüyle beraber ortaya çıkan taht mücadelelerinin de temel sebebini teşkil etmektedir. Yine bu anlayış çerçevesinde bakıldığında hanedan üyelerinin yer yer taht için mücadeleye girişmesi devletin sürekliliğini ve güçlü bir otorite oluşturmasını da engellemiştir. Bu bağlamda ortaya çıkan bu siyasi olayların anlaşılabilmesi için merkezi otoriteye karşı çıkan mücadele hareketlerinin sebeplerini ve neticelerini iyi analiz etmek gerekmektedir.

Bu bağlamda ele alınan Sultan Sencer döneminde yaşanan Saltanat Mücadeleleri ekseninde, ülkenin içine düştüğü durum hiç de iç açıcı değildir. Bir bakıma Selçuklu Devleti'nin sonunu getiren Saltanat Mücadeleleri, Sultan Sencer döneminde önü alınamaz hale gelmiş bu durum devletin komşusu konumundaki diğer devletlerle de ilişkilerinin zayıflamasına ve söz konusu devletlerin Selçuklunun daha da zayıflamasında hızlandırıcı etkiye sebep olmuştur. 
Son aşamada Sultan Sencer'in Ŏguzlara esir düşmesi ve devlet idaresinde oluşan uzun süreli boşluk telafisi mümkün olmayan zararlar ortaya çıkarmıştır. Her ne kadar ülkeyi ayakta tutmaya çalışan Sultan Sencer bu konuda yeterince başarı gösterememiş özellikle çevresinin etkisi altında kalan Sultan Selçuklu Devleti'nin son hükümdarı olarak tarih kitapları arasında yerini almıştır.

Sultan Sencer, hükümdarlığı süresince ülkesinde; ilim, edebiyat ve sanatın gelişmesine oldukça destek olan büyük bir hükümdar olarak bilinmektedir. O bilim adamlarına en çok saygı ve hürmet eden Selçuklu hükümdarlarından biridir. Akıllı, adaletli, heybetli, cömert, güzel ahlaklı ve yumuşak tabiatlı bir insan olan Sultan Sencer, affetmeyi seven, halka karş1 merhametli davranan bir hükümdardır. Ve yine Sultan Sencer'in döneminde halk güven içerisinde yaşamıştır. O kılıçla topladığını kalemle dağıtan, esir aldığı hükümdarlara iyi davranan vasıflı bir Sultandır ${ }^{10}$.

Son hükümdar Sultan Sencer'in ölümü ile birlikte Selçuklu Devleti de tarih sahnesinden çekilmek zorunda kalmış, bundan sonraki Selçuklu izleri parçalar halinde kendini göstermeye devam etmiştir.

\section{Kaynaklar}

Barthold, V.V. (1990), Moğol İstilâsına Kadar Türkistan, Haz: H. Dursun Yıldız, TTK Yayınları ,Ankara, ss. 644.

Çayci, A. (2008), Selçuklularda Egemenlik Sembolleri, İz Yayıncılık, İstanbul, ss, 325.

Göksu, E. (2010). Türkiye Selçuklularında Ordu, TTK. Ankara, ss, 469.

İbnu'1 Esir, el Kâmil fì't-Tarih, C. IX,X,XI,XII, yay, Carolus Johannes Tornberg, Beyrut 1966; Çev., Abdülkerim Özaydın, C. IX,X,XI,XII, İstanbul, 1987.

kafesoğlu, İ.(1992), Selçuklu Tarihi, Tarih Dizisi, M.E.B., İstanbul, ss, 125.

(2000), Harezmşahlar Devleti Tarihi (485-618/1092-1221), TTK, Ankara, ss,

315.

kaya, P. (2013), Sultan Sencer Devrinde (1118-1157) Bâtıniler İle Yapılan Mücadeleler, Tarih Dergisi, S,58 (2), İstanbul, ss, 43-64.

Kivameddin Burslan, (1999), Irak ve Horasan Selçukluları Tarihi, TTK, Ankara, ss, 232-252.

Koca, S. (2009). "Selçuklu İktidarının Belirlenmesinde Rol Oynayan Güçler ve Alâeddîn Keykubâd'ın Türkiye Selçuklu Tahtına Çıkışı", SÜTAD, S. 25, Konya, ss, 1-38.

Köprülü, M. F, "Harizmşahlar”, İA, s, 265-267.

Köymen, M. A. "Sencer", İA, X, ss, 486-493.

1991), Büyük Selçuklu Imparatorluğu Tarihi V- Íkinci İmparatorluk Devri, TTK,

Ankara, ss, 488.

2011), Büyük Selçuklu Imparatorluğu Tarihi II- İkinci Imparatorluk Devri, TTK,

Ankara, ss, 524 ..

2016). Büyük Selçuklu Imparatorluğu Tarihi III- Alp Arslan ve Zamanı, TTK,

Ankara, ss, 532.

(1989). Selçuklu Devri Türk Tarihi, TTK, Ankara, ss, 310.

Merçil, E. (1991), Müslüman-Türk Devletleri Tarihi, TTK, Ankara, ss, 411.

-(2007), Gazneliler Devleti Tarihi, TTK, Ankara, ss, 138.

-(2007). Selçuklularda Hükümdarlık Alâmetleri, TTK, Ankara, ss,283.

Öngül, A. (2014). Selçuklular Tarihi I Büyük Selçuklular, Irak, Kirman ve Suriye Selçukluları, Çamlıca Yayınları, İstanbul, ss, 545

\footnotetext{
${ }^{10}$ Kaynaklarda Sultan Sencer ile ilgili olarak birçok menkıbe bulmak mümkündür. Daha fazla bilgi için bkz. Kıvameddin Burslan, (1999), Irak ve Horasan Selçukluları Tarihi, TTK, Ankara, s, 232-252; A. Sevim-E. Merçil, (2014). age, s, 284-285; A. Öngül, (2014), age, s, 258.
} 
(2014), Selçuklular Tarihi II Anadolu Selçukluları ve Beylikler, Çamlıca Yayınları, İstanbul, ss, 416.

Sümer, F. "Mes'ûd”, İA, VIII, 134-142.

Sevim, A.- Merçil, E. (2014), Selçuklu Devletleri Tarihi Siyaset, Teşkilat ve Kültür, TTK, Ankara, ss, 768.

Turan, O. (2014). (2003). Selçuklular Tarihi ve Türk-İslam Medeniyeti, Ötüken Yayınları, İstanbul, ss, 542.

Yazici, N. (2014), İlk Türk-İslam Devletleri Tarihi, Diyanet Vakfı Yayınları, Ankara, ss, 447. 